\title{
MISCELLANEA
}

\author{
Tadeusz Oracki
}

O POCHODZENIU KRÓLEWIECKIEGO PROFESORA MEDYCYNY ANDRZEJA JANA ORLOVIUSA (ORŁOWSKIEGO)

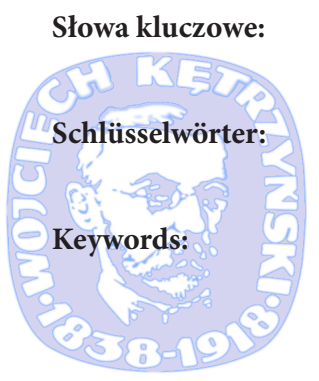

\begin{abstract}
Prozopografia, lekarze z Królewca, Andrzej Jan Orlovius, historia medycyny

Prosopographie, Ärzte aus Königsberg, Andreas Johannes Orlovius, Geschichte der Médizin
\end{abstract}

Prosopography, doctors from Königsberg, Andreas Johannes Orlovius, history of medicine

Andrzej Jan Orłowski (1735-1788), który zgodnie z ówczesnym zwyczajem pisał się przeważnie jako Orlovius, był osobą znaną i cenioną nie tylko w naukowym środowisku akademickim w Królewcu, gdzie był profesorem medycyny, kilkakrotnie dziekanem i rektorem Uniwersytetu Królewieckiego ${ }^{1}$. Ogłosił kilkadziesiąt rozpraw naukowych (wyłącznie w języku łacińskim), przeprowadzał eksperymenty medyczne, z jego usług korzystała elita polsko-litewska, utrzymywał kontakty z ośrodkami naukowymi w Niemczech i w Polsce (głównie z Wilnem)2. Wydawać by się mogło, że biografia tego uczonego jest znana, a różne fakty z jego życia i działalności nie budzą wątpliwości.

Niestety, jego biogram w opracowaniu naukowym nie znalazł się w najważniejszych słownikach biograficznych niemieckich (Allgemeine Deutsche Biographie, Neue Deutsche Biographie, Altpreussische Biograpie) i polskich (Polski Stownik Biograficzny). Szczególne wątpliwości budzi sprawa pochodzenia Orloviusa (Orłowskiego). Począwszy od osiemnastowiecznych autorów niemieckich J.F. Goldbecka

\footnotetext{
1 Najobszerniejszy biogram naukowy znajduje się w Słowniku biograficznym Warmii, Prus Książęcych i Ziemi Malborskiej od połowy XV do końca XVIII wieku, T. 2, Olsztyn 1988, ss. 67-68, opracowanym przez T. Orackiego.

2 Estreicher uwzględnił jedynie trzy jego prace, podając przy tym błędne daty biograficzne. Zob. Bibliografia polska, T. XXIII, Kraków 1910, s. 428.
} 
i D.H. Arnoldta ${ }^{3}$ oraz późniejszych polskich, J.S. Bandtkiego i L. Gąsiorowskiego, a także autorów haseł w największych encyklopediach ${ }^{4}$, przyjęto powszechnie informację, że Orlovius (Orłowski) urodził się w Wilnie więc jest Litwinem. Podobnie postąpili autorzy specjalistycznych i regionalnych słowników biograficznych ${ }^{5}$.

To prawda, ze Orłowski urodził się w Wilnie, ale jego rodzice pochodzili z miejscowości Eckersberg (Okartowo) leżącej w powiecie piskim na terenie dawnych Prus Książęcych. Nie jest więc Orłowski Litwinem tylko Mazurem pruskim, o czym świadczą życiorysy jego rodziców.

W południowej części Prus Książęcych, na tak zwanych Mazurach Pruskich, roi się od Orłowskich (Orloviusów), którzy pełnili funkcje pastorów, nauczycieli i kantorów ${ }^{6}$. Od XVI wieku kilkudziesięciu z nich studiowało na Uniwersytecie Królewieckim ${ }^{7}$. Z tego środowiska, które można określić jako inteligencję mazurską, wywodzi się Jerzy Andrzej Orlovius, urodzony w 1693 roku w miejscowości Eckersberg (Okartowo) w powiecie piskim, w której jeszcze w pierwszej połowie XIX wieku, większość mieszkańców posługiwała się językiem polskim ${ }^{8}$ Ojciec naszego profesora rozpoczął w 1708 roku studia medyczne na Uniwersytecie Królewieckim ${ }^{9}$, a w 1718 uzyskał tam doktorat medycyny na podstawie rozprawy De motu sanguinis in arteriis atque venis, geometrice determinato ${ }^{10}$. W ogłoszonej drukiem rozprawie autor dziękuje swoim mecenasom: biskupowi wileńskiemu Konstantemu Kazimierzowi Brzostowskiemu, biskupowi sufraganowi i referendarzowi litewskiemu Maciejowi Józefowi Ancucie oraz podskarbiemu i hetmanowi wielkiemu litewskiemu Ludwikowi Konstantemu Pociejowi ${ }^{11}$.

Jerzy Andrzej Orłowski osiadł na stałe w Wilnie, został lekarzem nadwornym wojewody wileńskiego oraz lekarzem sztabowym armii. Prowadził także praktykę

3 J. F. Goldbeck, Litterarische Nachrichten vob Preussen, Berlin 1781, s. 90; D.H. Arnoldt, Zusätze zu seiner Historie der Königsbergschen Universität, Königsberg 1769, ss. 42, 44.

4 J.S. Bandtkie, Historia drukarń w Królestwie Polskim i Wielkim Księstwie Litewskim, T. 3, Kraków 1826, s. 84; L. Gąsiorowski, Zbiór wiadomości do historii sztuki lekarskiej w Polsce. T. 3, Poznań 1854, ss. 154-155; Encyklopedia powszechna (Orgelbranda), T. 20, Warszawa 1865, ss. 53-54; Wielka encyklopedia powszechna ilustrowana. Seria II, t. 6, Warszawa 1908, s. 591.

5 S. Kośmiński, Słownik lekarzów polskich, Warszawa 1888, ss. 369, 617; Biographisches Lexikon der hervorragenden Ärzte aller Zeiten und Völker, 2 Auflage, Berlin-Wien 1932, s. 441; A. Skrobacki, Polacy na Wydziale Lekarskim Uniwersytetu w Królewcu, Olsztyn 1969, ss. 94-95; T. Oracki, zob. przypis 1; M. Jackiewicz, Nauka i uczeni na ziemi wileńskiej od XVI w. do 1945 r., Bydgoszcz 2010, s. 283.

6 L. Rhesa, Kurzgefaste Nachrichten von allen seit 1775 an den evangelischen Kirchen In Ostpreussen, Königsberg 1834, ss. 132, 133; H.W. Quassowski, Die Kartei Quassowski. Buchstabe O, Hamburg 1985, ss. 67-68.

G. Erler, Die Martikel der Albertus - Universität zu Königsberg i.Pr., Bd I, Leipzig 1910, ss. 6, 66, 231, 268; Bd II, Leipzig 1911/12, ss. 106, 260, 299, 443, 447, 476, 486, 495, 721.

8 K.A. Maczkowski, Eckersberg und seine Umgebung. Geschichte, Beschreibung und Urkunden, Hamburg 1985, ss. 60, 76-83; W. Chojnacki, Zbory polsko-ewangelickie w bylych Prusach Wschodnich w XVI-XX w. Reformacja w Polsce. R. 12: 1953-1955, nr 45-50, s. 268.

9 G. Erler, op. cit., II, s. 260

10 M. Komorowski, Promotionen an der Universität Königsberg 1548-1799, München 1988, s. 27 (nr 117). Rozprawa J.A. Orloviusa znajduje się w zbiorach Biblioteki Gdańskiej PAN. Sygn. 31 in: XIX qu 83 K.

11 Życiorysy wymienionych w Polskim Słowniku Biograficznym, t. I, Kraków 1935, ss. 90-91, t. III. Kraków 1937, ss. 50-52, T. XXVII, Wrocław 1983, ss. 38-47. 
lekarską. Zmarł w Wilnie 18 czerwca 1743 roku $^{12}$. Wcześniej, w 1737 roku, zmarła jego żona. Oboje zostali pochowani na cmentarzu ewangelickim w Wilnie ${ }^{13}$.

Andrzej Jan Orlovius - Orłowski urodził się w Wilnie 31 grudnia 1737 roku i poszedł w ślady ojca. Po ukończeniu miejscowej szkoły w 1752 wpisał się na studia medyczne w Uniwersytecie Królewieckim jako „Vilna - Lithuan” ${ }^{4}$, uzyskując w 1761 roku doktorat medycyny ${ }^{15}$.

Autorzy piszący o Orłowskim nie zwrócili uwagi na fakt zbyt długo trwających studiów, zwłaszcza że podobnie jak ojciec, był człowiekiem inteligentnym i uzdolnionym. Prawdopodobnie przez pewien czas Orlovius przebywał w Wilnie, gdzie istniał gabinet medyczny po zmarłym ojcu. Autorom biogramów Orłowskiego nie był znany drugi, tym razem kurtuazyjny wpis tego medyka do metryki Uniwersytetu Królewieckiego, który miał miejsce w 1765 roku. Czytamy tam, że Orlovius „vir praestantissimus, Vilna - Lithuan., ex Polonia redux, dr med. In Acamedia nostra rite promotus Ius Academicum repetiit ..."16. Informacja jasna: wrócił z Polski, ale co tam porabiał? Posiadając doktorat medycyny i prawo do praktyki prywatnej, z pewnością udzielał w Wilnie porad lekarskich. Świadczą o tym pamiętniki Marcina Matuszewicza (1714-1773), kasztelana brzesko-litewskiego1, który wspomina, że leczył go „sławny i bardzo wielkiej eksperiencji doktor”, a w innym miejscu dodaje, że w roku 1762 Orłowski, „syn sławnego doktora Orłowskiego”18 leczył hetmana polnego litewskiego, Michała Massalskiego ${ }^{19}$.

Wkrótce po powrocie do Królewca Orłowski został profesorem (1766) i jak wspomniano, kilkakrotnie pełnił funkcje dziekana i rektora; nadto był członkiem Kolegium Medycznego i Sanitarnego w Królewcu ${ }^{20}$.

Prof. Orłowski ustanowił dwie fundacje stypendialne w Uniwersytecie Królewieckim (Stipendium Orlovianum) ${ }^{21}$, a jego cenny księgozbiór opisany w katalogu aukcyjnym wystawiono na sprzedaż po śmierci właściciela ${ }^{22}$.

12 D.H. Arnoldt, Ausführliche und mit Urkunden versehene Historie der Königsbergischen Universität. 2 Teil, Königsberg 1746, s. 173; Pamiętniki Marcina Matuszewicza kasztelana brzesko-litewskiego 1714-1765, wyd. A. Pawiński, t. I, Warszawa 1876, s. 7, 63; Quassowski, op. cit., s. 67.

13 A.F.A. (A.F. Adamowicz), Kościół augsburski w Wilnie. Kronika, Wilno 1855, s. 33; E. Małachowicz, Wilno. Dzieje, architektura, cmentarze, Wrocław 1996, s. 438.

14 G.Erler, op. cit., Bd II, s. 447.

15 M. Komorowski, op. cit., ss. 40, 45, 208-209.

16 G. Erler, op. cit., Bd II, s. 499.

17 Z. Zielińska, Matuszewicz Marcin (1714-1773), Polski Słownik biograficzny, t. XX, Wrocław 1975, ss. 222-224.

18 Pamiętniki M. Matuszewicza, op. cit., T. I, s. 63, t. III s. 173.

19 Z. Zielińska, Massalski Michał Józef (1700-1768), Polski Słownik Biograficzny, t. XX, Wrocław 1975, ss. $141-143$.

20 K. Hüllmann, Das Stammbuch des Marienburger Pfarrers Wilhelm L. Häbler, Altpreussische Geschlechterkunde 6:1932, s. 15 .

${ }_{21}$ Sammlung der bei der Königlichen Albertus Universität zu Königsberg bestehenden staatlichen und privaten Benefizien für Studierende, hrsg. E. Wollenberg, Königsberg 1911, s. 66.

22 J. Tondel, Książka w dawnym Królewcu pruskim, Toruń 2001, s. 199. 
Andrzej Jerzy Orłowski (Orlovius), który zmarł w Królewcu 28 lutego 1788 roku z pewnością zasługuje na obszerniejsze opracowanie.

Tadeusz Oracki, Über Herkunft des Königsberger Medizinprofessors Andrzej Jan Orlovius (Orłowski)

Zusammenfassung

Der Beitrag betrifft Andrzej Jan Orlovius (Orłowski), Medizinprofessor in Königsberg, der in den Jahren 1735-1788 lebte. Der Artikel ergänzt wesentlich die bisherigen Arbeiten, in denen er als Litauer bezeichnet wurde, obwohl er aus einer masurischen Familie stammte, die seit alters her in Herzogtum Preußen wohnte.

Übersetzt von Alina Kuzborska

Tadeusz Oracki, On the Origin of the Königsberg Professor of Medicine, Andrzej Jan Orlovius (Orłowski)

Summary

This article concerns Andrzej Jan Orlovius (Orłowski), living in the years 1735-1788, professor of medicine in Königsberg, and is an important supplement to the research to date, in which he was mentioned as a Lithuanian, whilst in fact he derived from a Masurian family in Prussia.

Translated by Aleksander Pluskowski

Prof. dr hab. Tadeusz Oracki

Wydział Filologiczno-Historyczny

Uniwersytet Gdański

\section{Źródła drukowane}

Hüllmann Kurt

1932 Das Stammbuch des Marienburger Pfarrers Wilhelm L. Häbler, Altpreussische Geschlechterkunde 6:1932, ss. $10-16$.

Matuszewicz Marcin

1876 Pamiętniki Marcina Matuszewicza kasztelana brzesko-litewskiego 1714-1765, wyd. A. Pawiński, t. I-III, Warszawa.

Sammlung der bei der Königlichen Albertus Universität zu Königsberg

1911 Sammlung der bei der Königlichen Albertus Universität zu Königsberg bestehenden staatlichen und privaten Benefizien für Studierende, hrsg. E. Wollenberg, Königsberg.

\section{Opracowania}

Adamowicz Adam Ferdynand (A.F.A)

1855 Kościół augsburski w Wilnie. Kronika, Wilno 1855.

Arnoldt Daniel Heinrich

1746 Ausführliche und mit Urkunden versehene Historie der Königsbergischen Universität, 2 Teil, Königsberg.

1769 Zusätze zu seiner Historie der Königsbergschen Universität, Königsberg.

Bandtkie JerzySamuel

1826 Historia drukarń w Królestwie Polskim i Wielkim Księstwie Litewskim, T. 3, Kraków. 
Biographisches Lexikon.

1932 Biographisches Lexikon der hervorragenden Ärzte aller Zeiten und Völker, 2 Auflage, Berlin-Wien.

Chojnacki Władysław

1955 Zbory polsko-ewangelickie w bylych Prusach Wschodnich w XVI-XX w., Reformacja w Polsce, R. 12, nr 45-50.

Erler Georg

1910-1911/12 Die Martikel der Albertus - Universität zu Königsberg i. Pr., Bd. I, Bd. II, Leipzig.

Estreicher Karol (opr.)

1910 Bibliografia polska. T. XXIII, Kraków.

Komorowski Manfred

1988 Promotionen an der Universität Königsberg 1548-1799, München.

Kośmiński Stanisław Lubicz

1888 Słownik lekarzów polskich, Warszawa.

Gąsiorowski Ludwik

1854 Zbiór wiadomości do historii sztuki lekarskiej w Polsce, T. 3, Poznań.

Goldbeck Johann Friedrich

1781 Litterarische Nachrichten von Preussen, Berlin.

Jackiewicz Mieczysław

2010 Nauka i uczeni na ziemi wileńskiej od XVI w. do 1945 r., Bydgoszcz.

Maczkowski Karl August

1985 Eckersberg und seine Umgebung. Geschichte, Beschreibung und Urkunden, Hamburg.

Małachowicz Edmund

1996 Wilno. Dzieje, architektura, cmentarze, Wrocław.

Oracki Tadeusz (opr.)

1988 Słownik biograficzny Warmii, Prus Książęcych i Ziemi Malborskiej od połowy XV do końca XVIII wieku. T. 2, Olsztyn.

Quassowski Hans Wolfgang

1985 Die Kartei Quassowski. Buchstabe O, Hamburg.

Rhesa Ludwig

1834 Kurzgefaste Nachrichten von allen seit 1775 an den evangelischen Kirchen in Ostpreussen, Königsberg.

Skrobacki Andrzej

1969 Polacy na Wydziale Lekarskim Uniwersytetu w Królewcu, Olsztyn.

Tondel Janusz

2001 Książka w dawnym Królewcu pruskim, Toruń.

Zielińska Zofia

1975a Matuszewicz Marcin (1714-1773), Polski Słownik biograficzny, t. XX, Wrocław, ss. 222-224.

1975b Massalski Michał Józef (1700-1768), Polski Słownik Biograficzny, t. XX, Wrocław, ss. 141-143. 


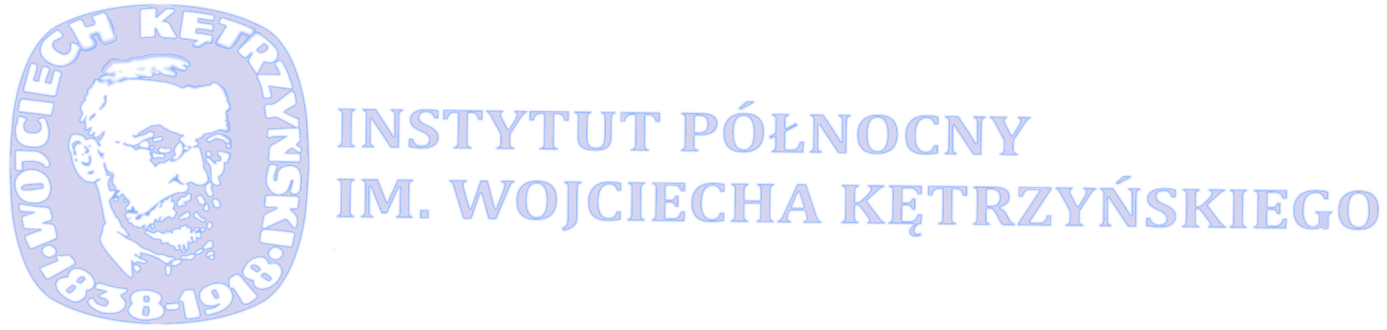

